\title{
In vitro antiplasmodial activity, cytotoxicity, antioxidant action and GC-FID analysis of Allanblackia floribunda Oliv
}

\author{
Francis Irabor ${ }^{1}\left([) \cdot\right.$ Osamudiamen Ebohon $^{1}$ (D) Nekpen Erhunse ${ }^{2,4}$ (i) $\cdot$ Osariemen T. Okugbo ${ }^{3}$ (D) \\ Ehimwenma S. Omoregie ${ }^{4}$ (i)
}

Received: 10 December 2020 / Accepted: 20 September 2021

Published online: 28 September 2021

(c) The Author(s) $2021 \quad$ OPEN

\begin{abstract}
This study evaluated the in vitro antiplasmodial efficacy and cytotoxicity of Allanbackia floribunda stem bark extract, leaf extract and oil. It also assessed the phytochemical compositions and antioxidant action of the stem bark fractions as well as the phytochemical fingerprint of the most active fraction (dichloromethane). Trager and Jensen method was used to culture Plasmodium falciparum, Mark III test developed by WHO was used to assess the antiplasmodial activity of the plant's crude extract and fractions against the ring stage of $P$. falciparum strain, Pf3D7. Cytotoxicity was determined against Vero cell line using microculture tetrazolium (MTT) test. Gas chromatography with flame ionization detection (GC-FID) was employed to identify phytochemical fingerprint of the most active fraction. The stem bark extract had better antiplasmodial activity $\left(I C_{50 P f 3 D 7}\right.$ of $\left.4.3 \pm 0.17 \mu \mathrm{g} / \mathrm{mL}\right)$ compared with the leaf extract $\left(I C_{50 P f 3 D 7}, 8.0 \pm 0.28 \mu \mathrm{g} / \mathrm{mL}\right)$ and oil $\left(\mathrm{IC}_{50 \mathrm{Pf3D} 7}>100 \mu \mathrm{g} / \mathrm{mL}\right)$. Both the leaf and stem bark extracts were found to be non-cytotoxic compared with the standard cytotoxic drug, doxorubicin. The selectivity indices (S.I.) of the extracts against the parasite were 20.06 and 8.85 for the stem bark and leaf respectively. Dichloromethane fraction had the highest inhibition against the $P$. falciparum parasite with $\mathrm{IC}_{50 \mathrm{Pf3D} 7}$ of $1.51 \mathrm{\mu g} / \mathrm{mL}$. GC-FID analysis showed high presence antiplasmodial flavonoids and terpenes. This investigation confirmed that $A$. floribunda stem bark has potent activity against $P$. falciparum, and it is relatively safe to normal cell.
\end{abstract}

\section{Article Highlights}

- Allanblackia floribunda methanol stem bark and leaf extracts could inhibit the growth of chloroquine sensitive Plasmodium falciparum (Pf3D7) in vitro.
- The stem bark infusion of Allanblackia floribunda was found to be nontoxic and safe at moderate doses to normal cell line (Vero cell line).

- Dichloromethane fraction of the stem bark showed excellent inhibition against chloroquine sensitive malaria parasite.

Keywords Antiplasmodial activity · Cytotoxicity · Plasmodium falciparum · Allanblackia floribunda · Phytochemical fingerprint

Supplementary Information The online version contains supplementary material available at https://doi.org/10.1007/s42452-02104812-0.

$\triangle$ Francis Irabor, francis.irabor@yahoo.com | ${ }^{1}$ Department of Biological and Chemical Sciences, Faculty of Natural and Applied Sciences, Michael and Cecilia Ibru University Agbarha-Otor, P.M.B 100, Ughelli, Delta State, Nigeria. ${ }^{2}$ International Centre for Genetic Engineering and Biotechnology, New Delhi, India. ${ }^{3}$ Department of Basic Sciences, Faculty of Basic and Applied Sciences, Benson Idahosa University, Benin City, Nigeria. ${ }^{4}$ Department of Biochemistry, Faculty of Life Sciences, University of Benin, P.M.B 1154, Benin City, Nigeria.

SN Applied Sciences $\quad$ (2021) 3:820 | https://doi.org/10.1007/s42452-021-04812-0 


\section{Introduction}

Malaria is a disease that is caused by Plasmodium parasite. The symptoms and clinical manifestations of this protozoan infection is severe when the infection is caused by Plasmodium falciparum in children, pregnant women and individuals from malaria free regions [1]. However, the negative impact of $P$. falciparum is less complicated when previously exposed to the parasite infection [1]. Though Artemisinin-based combination therapy (ACT) recommended by WHO for the treatment of uncomplicated malaria has been effective in combating this malady. but the scourge of the disease is still fierce in sub-Saharan Africa because of the mortality rate on a yearly basis [2]. For example, there were approximately $216,000,000$ cases of malaria infection worldwide resulting in 445,000 death with $91 \%$ of the mortality in Africa [2]. It has been impossible to eliminate malaria from Africa due to the existence of hard-to- reach communities, inaccessibility of antimalarial drugs, exposure to fake antimalarial drugs, drug resistance, lack of information flow on effective antiplasmodial agents and individuals' low-income status. In addition, recent reports in eastern [3], northern and southern [4, 5] regions of Nigeria suggest possible cases of parasite resistance and recrudescence to the currently used combined antimalarial therapies. The present circumstances necessitate the need for alternative antimalarial drug and adjuvant therapy to curtail the challenges of parasite elimination and curb possible future resistance.

Despite the death toll resulting from parasite plaque in Nigeria, the tribals of southern Nigeria are able to control the ravaging effect to some extent by using plant infusion from Allanblackia floribunda commonly known as elephant rice $[6,7]$. A. floribunda is rich in bioactive substances with varied pharmacological properties on living systems $[6,7]$. The stem bark, leaf and fruit of $A$. floribunda infusions are used in African herbal medicine preparation to manage pain and inflammation. In Nigeria, Ghana, Cameroon and Ivory Coast the stem bark extract is used to heal aching tooth and asthma, the pounded bark is used traditionally to stop diarrhea, a decoction of the whole fruit is used to relieve scrotal elephantiasis $[6,7]$ and the stem back infusion is used to maintain strong erection in aging men [8].

Preliminary phytochemical screening of the stem, leaf and oil showed that stem has more phenolics, flavonoids, terpenoids compared with the leaf extract and oil [Irabor et al., unpublished]. The methanol extract of a close species, Allanblackia parviflora Chev. was reported to have a strong antimicrobial activity against Entaemoeba faecalis [9]. In 2017, high performance liquid chromatography analysis of methanol extract of the seed by Akpanika et al. [10] revealed the presence of important polyphenols (morelloflavone) and glucosides and their antioxidant activities were comparable to vitamin C.

Despite the relevance of $A$. floribunda in Africa folk medicine there exist a limited scientific data and documentation on its antimalarial activity, the relative abundance of its pharmacologically active substances, best solvent for its extraction and level of safety of its most active infusions. This investigation therefore examined the in vitro antiplasmodial activity, cytotoxicity, antioxidant action and GC-FID analysis of Allanblackia floribunda extracts.

\section{Materials and methods}

\subsection{Plant collection and identification}

The plant parts used in this study were selected based on ethnopharmacological information as antimalarial agents used in southern part of Nigeria. Allanblackia floribunda leaf, stem bark and seed were collected during the period of January and July 2016, from a forest area at Ohogua community, Ovia East Local Government, Benin City, Edo Sate, Nigeria. The plant was authenticated by Dr. Henry A. Akinnibosun at the Department of Plant Biology and Biotechnology, Faculty of Life Sciences, University of Benin, Nigeria, and voucher specimen of the sample $\left(\mathrm{UBHA}_{\mathbf{3 6 1}}\right)$ was deposited at the herbarium of the same department. The plant scientific name was checked with http://www. theplantlist.org on 26th October, 2020.

\subsection{Preparation of extract}

A $100^{\circ} \mathrm{g}$ of the $A$. floribunda stem bark and leaf were macerated in $1000 \mathrm{~mL}$ of absolute methanol for $72 \mathrm{~h}$ with occasional stirring. The extracts were then filtered using double layered muslin cloth and the filtrate concentrated to dryness by using a rotary evaporator at reduced pressure while the oil was obtained from about $200 \mathrm{~g}$ of the powdered seed using hot water floatation method. The extracts obtained were stored at $4^{\circ} \mathrm{C}$ until used.

\subsection{Cultivation of parasites}

Trager and Jensen procedure was used to culture $P$. falciparum $[11,12]$. The Plasmodium strain (Pf3D7) used was chloroquine sensitive isolate obtained from the Malaria Research and Reference Reagent Resource Center (MR4) at the American Type Culture Collection (ATCC) in Manassas, Virginia, US. The parasites were cultured in $\mathrm{O}+\mathrm{RBC}$ as host cells and maintained in RPMI 1640 medium supplemented with gentamicin solution $0.01 \mathrm{mg} / \mathrm{mL}, 25 \mathrm{mM}$ 
HEPES buffer, $25 \mathrm{mM} \mathrm{NaHCO}_{3}$ and 1\% Albumax II maintained in $5 \% \mathrm{CO}_{2}$ and incubated at $37^{\circ} \mathrm{C}$. Parasitaemia was determined using light microscopy (Giemsa stain).

\subsection{In vitro antiplasmodial activity}

The growth inhibition of chloroquine-sensitive Plasmodium falciparum strain (Pf3D7) by the plant extracts was evaluated by means of the Mark III test, as developed by WHO [13]. The stock solutions were filter-sterilised through a $0.2 \mu \mathrm{m}$ Millipore filters. Two-fold serial dilutions of drug/ extracts were performed to generate required concentrations (refer to supplementary file S2) for treatment of parasitized cells in vitro. One hundred microliters $(100 \mu \mathrm{L})$ of $0.5 \%$ P. falciparum culture that had been synchronized (refer to supplementary file $\mathrm{S} 1$ ) was aliquoted into the wells of the pre-treated 96-well microtitre plate to a final hematocrit of $3 \%$. Wells with parasitized red blood cells without plant extract serve as negative controls whereas wells containing cultures with chloroquine diphosphate serve as positive control. Parasitaemia was evaluated after $48 \mathrm{~h}$ by Giemsa stain and the average suppression of parasitaemia was calculated by using the formula below: humidified $5 \% \mathrm{CO}_{2}$ atmosphere. After $48 \mathrm{~h}$, the medium was discarded by inversion of the microtitre plate and thereafter replaced with $100 \mu \mathrm{L}$ of fresh culture medium followed by $100 \mu \mathrm{L}$ of crude plant extract at a concentration of $2000 \mu \mathrm{g} / \mathrm{mL}$ in row $\mathrm{H}$ of the 96 well plate and serially diluted twofold to give concentrations ranging from 1000 to $1.95 \mu \mathrm{g} / \mathrm{mL}$. Row A of the 96 well plate serve as control wells. Doxorubicin was used as standard cytotoxic drug and concentration range tested for doxorubicin was $5-0.01 \mathrm{ug} / \mathrm{mL}$. The cells were maintained at $37^{\circ} \mathrm{C}$ in a $\mathrm{CO}_{2}$ incubator before determining their viability by using MTT assay as described by Mosmann [15] The absorbance for each well was measured between $490 \mathrm{~nm}$ in a micro-titre plate reader and the percentage cell viability (CV) was calculated using the formula below. A dose-response curve was plotted to calculate the concentration that resulted in $50 \%$ death of viable cells $\left(\mathrm{CC}_{50}\right)$.

$\mathrm{CV}=\frac{\text { Average Absorbance of duplicate drug wells }}{\text { Average absorbance of control well }} \times 100$

Average $\%$ parasitaemia in control - Average $\%$ parasitaemia in test

Average \% parasitaemia in control

The antiplasmodial activities of the extracts were expressed using $I C_{50}$. Each sample was tested in triplicate and the $\mathrm{IC}_{50}$ obtained were pooled and expressed as geometric means and standard deviations. The independent sample t-test was used to compare mean $\mathrm{IC}_{50}$ of antimalarial activity between plant extracts. Finally, the in vitro antiplasmodial activity was rated in accordance with the system of antiplasmodial activity of Rasoanaivo et al. [14]. According to this system, an extract is regarded to be very active if $I C_{50}$ is less than $5 \mu \mathrm{g} / \mathrm{mL}$, active if $I C_{50}$ is greater than $5 \mu \mathrm{g} / \mathrm{mL}$ but less than $50 \mu \mathrm{g} / \mathrm{mL}$, weakly active if $I C_{50}$ is greater than 50 but less than $100 \mu \mathrm{g} / \mathrm{mL}$ and inactive if $\mathrm{IC}_{50}$ is greater than $100 \mu \mathrm{g} / \mathrm{mL}$.

\subsection{Cytotoxicity test (cell viability assay)}

Vero cells were provided by the National Veterinary Research Institute, Vom Jos, Plateau State, Nigeria to assess the cytotoxicity of the most active plant extracts. Vero cells were maintained in Dulbecco's Modified Eagle's medium (DMEM) supplemented with $10 \%$ fetal bovine serum (FBS), glutamine $(2 \mathrm{mM})$, penicillin (100 units $/ \mathrm{mL})$ and streptomycin $(100 \mu \mathrm{g} / \mathrm{mL})$. The cells were seeded in 96 well plates at 10,000 cells per well in 100 $\mu \mathrm{L}$ culture medium. The cells were incubated at $37^{\circ} \mathrm{C}$ in a

\subsection{Fractionation of $A$. floribunda stem bark extract}

The stem bark extract was most active against Plasmodium falciparum (Pf3D7) compared with the leaf extract and oil of $A$. floribunda hence it was fractionated. Fractionation of the stem bark extract was done using solvent of increasing polarity as described by Hassan et al. [16]. The methanol stem bark extract of $A$. floribunda was partitioned into fractions of $n$-hexane, dichloromethane, ethyl acetate and hydromethanol. The fractions obtained were concentrated using a rotary evaporator (RE 300, Bibby Scientific, UK) with reduced pressure at $45^{\circ} \mathrm{C}$.

\subsection{Qualitative phytochemical screening and antioxidant activity of $A$. floribunda stem bark fractions}

The qualitative test for phytochemicals present in fractions were carried out using standard procedures $[17,18]$. The free radical scavenging capacity of the fractions against 1,1-diphenyl-2-picrylhydrazyl (DPPH) radical was determined by the method of Brand-Williams et al. [19] and phosphomolybdate reduction capacity was estimated using the method described by Prieto et al. [20]. 


\subsection{Gas chromatography (GC) analysis of most active fraction (dichloromethane fraction)}

The phytochemical fingerprint for flavonoids, terpenes, alkaloids, terpenoids, and volatile organic constituents of the most active fraction was determined using gas chromatography with flame ionization detector. Gas chromatography analysis was carried out on a HP 6890 Powered with HP ChemStation Rev. A 09 01[1206] Software. Active constituents were identified based on comparison of the retention times of the peaks with those of corresponding pure standard mixtures used. The flavonoids extraction was carried out by the method described by Millogo-Kone et al. [21]. The extraction of terpenes was carried out by method described by Ortan et al. [22]. The alkaloids extraction was carried out by the method described by Ngounou et al. [23]. The composition of volatile organic compounds was carried out on a HP 6890 powered with HP ChemStation Rev. Bioactive metabolites were identified based on comparison of the retention times of the peaks with those of the corresponding reference standards (Supelco Inc.) mixtures used (refer to supplementary file for the detailed methods of extraction and GC-FID conditions).

\subsection{Statistical analysis}

The various results obtained from this study were expressed as mean \pm SEM. One way analysis of variance (ANOVA) followed by Tukey's HSD (honest significant difference) test was used to determine significance differences between the groups. Statistical significance was declared when $P$ value was less than 0.05 . The statistical analysis was performed using the statistical package for social science (SPSS) for windows, version 16.0.

\section{Results}

\subsection{In vitro antiplasmodial activity of $A$. floribunda stem bark extract, leaf extract and oil}

The inhibition of parasite growth by the plant extracts was dose dependent from 0.78 to $25 \mu \mathrm{g} / \mathrm{mL}$. At about $5 \mu \mathrm{g} /$ $\mathrm{mL}$ and above, both leaf and stem bark extracts had over $45 \%$ parasite inhibition. However, A. floribunda oil extract recorded less than $40 \%$ of $P$. falciparum inhibition even at the highest dose (see Fig. 1a). The IC $\mathrm{C}_{50}$ values of the tested medicinal plant against $P$. falciparum are listed in Table 1 . The stem bark extract of $A$. floribunda showed excellent antiplasmodial activity $(4.3 \pm 0.17 \mu \mathrm{g} / \mathrm{mL})$ followed by the leaf extract $(8 \pm 0.28 \mu \mathrm{g} / \mathrm{mL})$. However, the oil extract showed IC ${ }_{50}$ value that was over $100 \mu \mathrm{g} / \mathrm{mL}$.
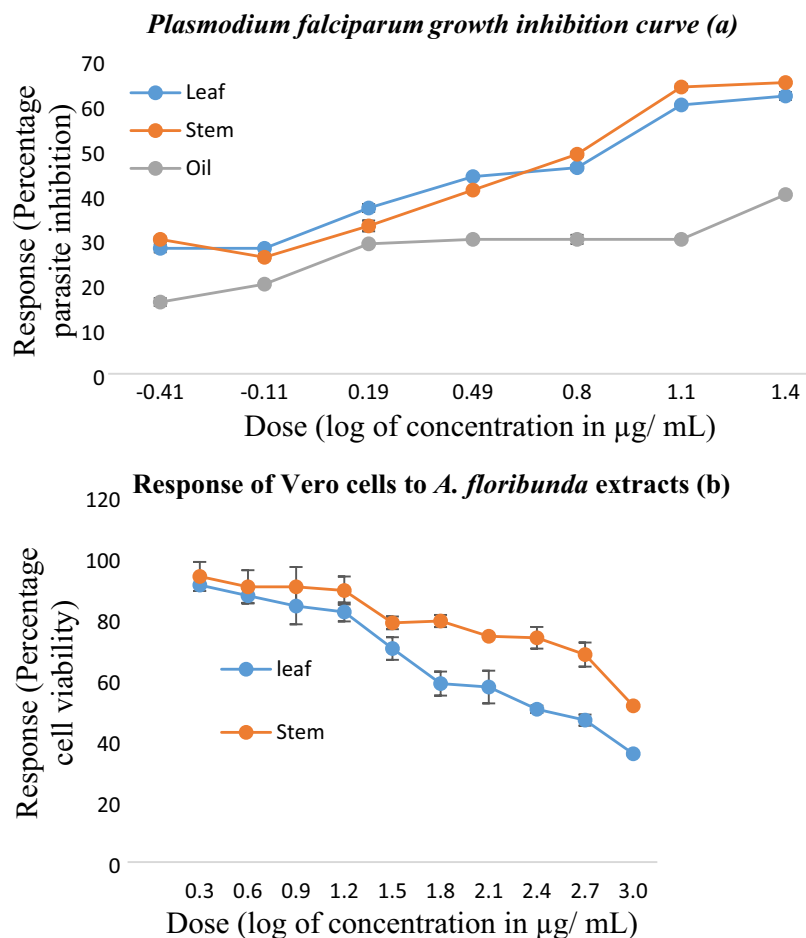

Dose (log of concentration in $\mu \mathrm{g} / \mathrm{mL}$ )

Response of Vero cells to doxorubicin (c)

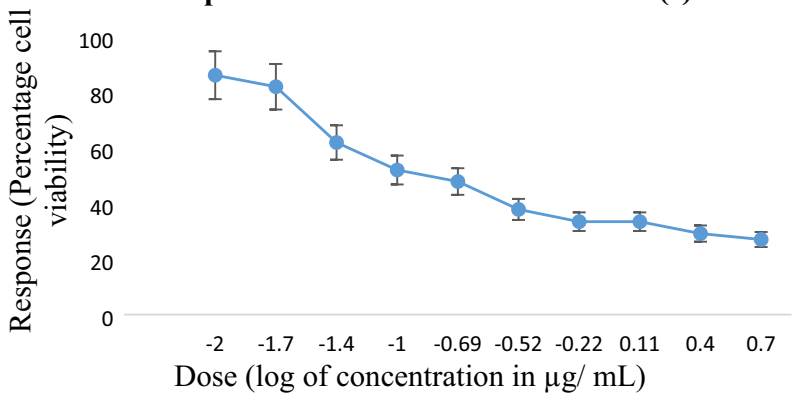

Fig. 1 Effects of A. floribunda extracts on: Plasmodium falciparum (Pf3D7) growth using Mark III test and cell viability in Vero cell using MTT assay

\subsection{Cytotoxic activity of $A$. floribunda crude stem and leaf extract}

Results of the cytotoxicity of $A$. floribunda stem bark extract, leaf extract and doxorubicin against Vero cell line are shown in Fig. $1 \mathrm{~b}$ and $1 \mathrm{c}$. The stem bark extract at 1.95 to $1000 \mu \mathrm{g} / \mathrm{mL}$ had cell viability that was majorly over $50 \%$. This same trend was observed for the leaf extract at 1.95 to $250 \mu \mathrm{g} / \mathrm{mL}$. However, we observed less than 50 percent cell viability at concentration greater than $250 \mu \mathrm{g} / \mathrm{mL}$ for the leaf extract. The methanol extracts of $A$. floribunda exhibited non significant activity against the Vero cell line with $\mathrm{CC}_{50}$ values of $88.26 \pm 0.15 \mu \mathrm{g} / \mathrm{mL}$ (stem bark) and $70.81 \pm 0.06 \mu \mathrm{g} / \mathrm{mL}$ (leaf) as shown in Table 1. The standard cytotoxic drug, doxorubicin was found to be highly cytotoxic having $\mathrm{CC}_{50}$ of $0.05 \pm 0.00 \mu \mathrm{g} / \mathrm{mL}$; the selectivity 
Table $1 \quad \mathrm{IC}_{50}, \mathrm{CC}_{50}$ values and selectivity index of $A$. floribunda extracts

\begin{tabular}{llll}
\hline Plant/Drug & $\begin{array}{l}\text { In vitro antiplasmodia activity } \\
\mathrm{IC} C_{50 \text { Pf3D } 7}(\mu \mathrm{g} / \mathrm{mL})\end{array}$ & $\begin{array}{l}\text { Cytotoxicity of Plant } \\
\text { Extract } \mathrm{CC}_{50}(\mu \mathrm{g} / \mathrm{mL})\end{array}$ & $\begin{array}{l}\text { Selectivity Index } \\
\mathrm{CC}_{50} / \mathrm{IC}_{50}\end{array}$ \\
\hline A. floribunda stem & $4.3 \pm 0.17^{\mathrm{a}}$ & $86.26 \pm 0.15^{\mathrm{c}}$ & 20.06 \\
A. floribunda leaf & $8 \pm 0.28^{\mathrm{b}}$ & $70.81 \pm 0.06^{\mathrm{b}}$ & 8.85 \\
A. floribunda oil & $>100 \pm 1.73^{\mathrm{c}}$ & $\mathrm{NA}$ & $\mathrm{NA}$ \\
Chloroquine & $1.76 \pm 0.01^{\mathrm{a}}$ & $\mathrm{NA}$ & $\mathrm{NA}$ \\
Doxorubicin & $\mathrm{NA}$ & $0.05 \pm 0.00^{\mathrm{a}}$ & $\mathrm{NA}$ \\
\hline
\end{tabular}

Data represent mean \pm SEM ( $n=3$ /group). Values in the same column with different lowercase letters represent significant difference between means at $p^{<} 0.05 ; \mathrm{NA}=$ Not applicable index for A. florinbunda leaf was lower (8.85) when compared with the stem bark extract (20.06) Table 1.

\subsection{Phytochemical composition, in vitro antiplasmodial and antioxidant activity of the partitioned fractions of $A$. floribunda methanol stem bark extract}

Table 2 depicts the phytochemical screening results of the partition fractions of $A$. floribunda most active infusion, stem bark extract. The result revealed the presence of quinones, flavonoids, cardiac glycosides, alkaloids, terpenoids, tannins and phenols in all the fractions. Majority of the phytochemicals were highly detected in the dichloromethane, ethylacetate and hydromethanol fractions. However, some of these bioactive compounds were less detected in the hexane fraction. Quinones were undetected in the hydromethanol fraction. Figure 2a represents the total antioxidant capacity obtained for the fractions of the stem bark extract; these results have similar pattern to the data obtained for the phytochemical screening of $A$. floribunda stem bark fractions. The reduction of molybdenum (VI) to molybdenum (V) by the fractions was highest in the hydromethanol $(205 \mu \mathrm{g} / \mathrm{mL})$ followed by ethylacetate fraction $(101.4 \mu \mathrm{g} / \mathrm{mL})$ and then the dichloromethane
$(93.2 \mu \mathrm{g} / \mathrm{mL})$. The hexane fraction had the lowest antioxidant activity $(82.4 \mu \mathrm{g} / \mathrm{mL})$. DPPH radical scavenging activity of the stem bark fractions of $A$. floribunda (Fig. 2b) was over $70 \%$ at a concentration range of 20 to $100 \mu \mathrm{g} / \mathrm{mL}$. An exception to this was the activity recorded for hexane fraction in which less than 60\% DPPH radicals were inhibited at $100 \mu \mathrm{g} / \mathrm{mL}$. Table 3 shows the $\mathrm{IC}_{50 \mathrm{DPPH}}$ of the various fractions as follow: ethylacetate $\left(\mathrm{IC}_{50 \mathrm{DPPH}}=14.62 \pm 0.41\right)$, hydromethanol $\left(\mathrm{IC}_{50 \mathrm{DPPH}}=5.26 \pm 0.55 \mu \mathrm{g} / \mathrm{mL}\right)$ and dichloromethane $\left(\mathrm{IC}_{50 \mathrm{DPPH}}=18.42 \pm 0.65\right)$. Ethylacetate, hydromethanol and dichloromethane fractions had better DPPH inhibiting ability compared to hexane fraction $\left(\mathrm{IC}_{50 \mathrm{DPPH}}=37.55 \pm 0.79 \mu \mathrm{g} / \mathrm{mL}\right)$ which was less active against free radical generated by DPPH.

The activity of the various fractions of $A$. floribunda stem bark with respect to inhibition of parasite growth is shown in Table 3 while Fig. 3 shows the dose response curve. Among the fractions, dichloromethane (DCM) had the best inhibitory potential against the $P$. falciparum parasite $\left(\mathrm{IC}_{50 \text { Pf3D7 }} 1.51 \mu \mathrm{g} / \mathrm{mL}\right)$. DCM was closely followed by the hydromethanol (HMet) fraction $\left(\mathrm{IC}_{50 \text { Pf3D7 }} 5.26 \pm 0.55\right)$ while that of ethylacetate (EAct) and hexane ( $\mathrm{Hxn})$ fractions were almost similar ( $I C_{50 \text { Pf } 3 D 7}=6$ and $6.25 \mu \mathrm{g} / \mathrm{mL}$, respectively). In general, the in vitro antiplasmodial activity of the fractions followed the order: DCM $>$ HMet $>$ EAct $>$ Hxn.

Table 2 Qualitative analysis of phytochemicals in A. floribunda fractions

\begin{tabular}{lllll}
\hline Phytochemicals & Hexane & Dichoromethane & Ethylacetate & Hydromethanol \\
\hline Phenolics & - & + & + & + \\
Terpenoids & + & ++ & +++ & +++ \\
Tannins & - & + & + & + \\
Alkaloids & - & + & + & + \\
Flavonoids & + & + & ++ & + \\
Quinones & - & + & ++ & ++ \\
Cardiac Glycosides & ++ & ++ & + \\
\hline
\end{tabular}

KEY: $+++=$ Very highly detected; $++=$ Highly detected; $+=$ Less detected $;-=$ Not detected 


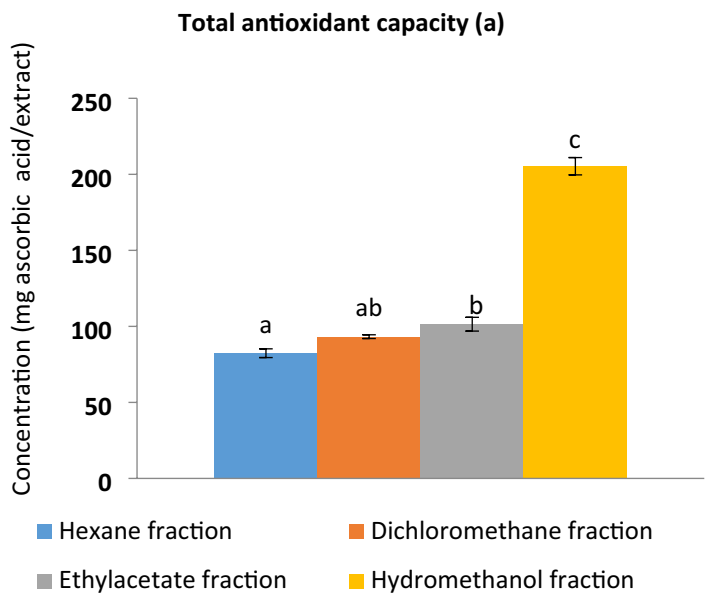

DPPH radical scavenging ability (b)

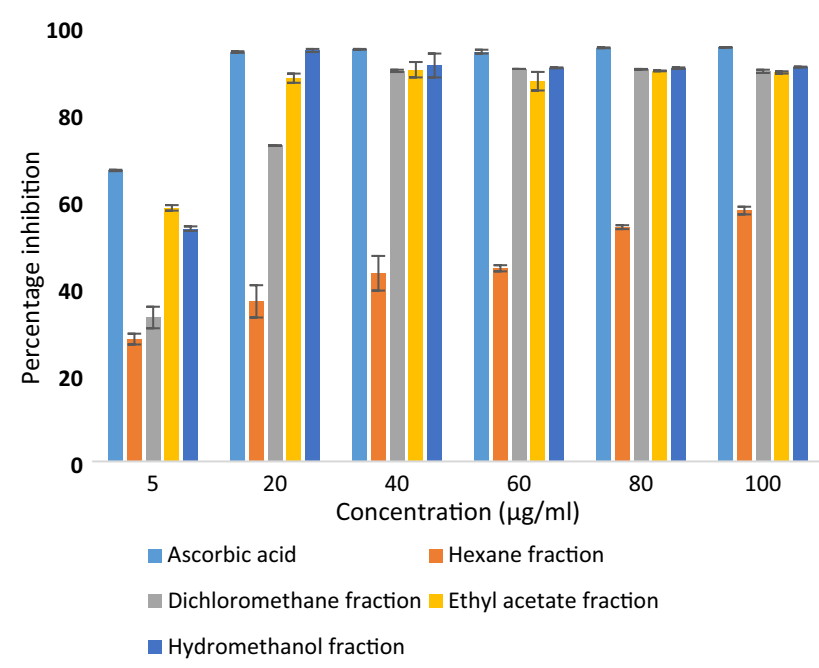

Fig. 2 Antioxidants capacity and free radical inhibiting activity of A. floribunda stem bark fractions a Total antioxidant capacity of $A$. floribunda stem bark fractions; $\mathbf{b}$ DPPH radical scavenging ability of A. floribunda stem bark fractions. Data are expressed as mean \pm SEM of results from three independent experiments. Bars with different lowercase letters represent significant difference between mean at $p^{<} 0.05$

Table $3 \quad I_{50-D P P H}$ and IC $\mathbf{C}_{50 \text { Pf3D7 of }} A$. floribunda stem bark fractions

\begin{tabular}{lrl}
\hline Fraction/Standard & $\mathrm{IC}_{50 \mathrm{DPPH}}(\mu \mathrm{g} / \mathrm{mL})$ & $\mathrm{IC}_{50 \text { Pf3D7 }}(\mu \mathrm{g} / \mathrm{mL})$ \\
\hline Vitamin C & $5.62 \pm 0.35^{\mathrm{a}}$ & $\mathrm{ND}$ \\
A. floribunda Hexane & $37.55 \pm 0.79^{\mathrm{d}}$ & $6 \pm 0.05^{\mathrm{b}}$ \\
$\begin{array}{l}\text { A. floribunda Dichlorometh- } \\
\text { ane }\end{array}$ & $18.42 \pm 0.65^{\mathrm{c}}$ & $1.51 \pm 0.04^{\mathrm{b} \mathrm{a}}$ \\
A. floribunda Ethylacetate & $14.62 \pm 0.41^{\mathrm{b}}$ & $6.25 \pm 0.05^{\mathrm{b}}$ \\
A. floribunda Hydro-methanol & $5.26 \pm 0.55^{\mathrm{a}}$ & $5 \pm 0.06^{\mathrm{b}}$ \\
\hline
\end{tabular}

Data represent ability of extracts to inhibit DPPH's radical and parasite growth by $50 \%$. Values represent mean \pm SEM of triplicate analyses; different lower-case letters in the same column indicates significant difference at $p<0.05 ; \mathrm{ND}=$ Not detectable

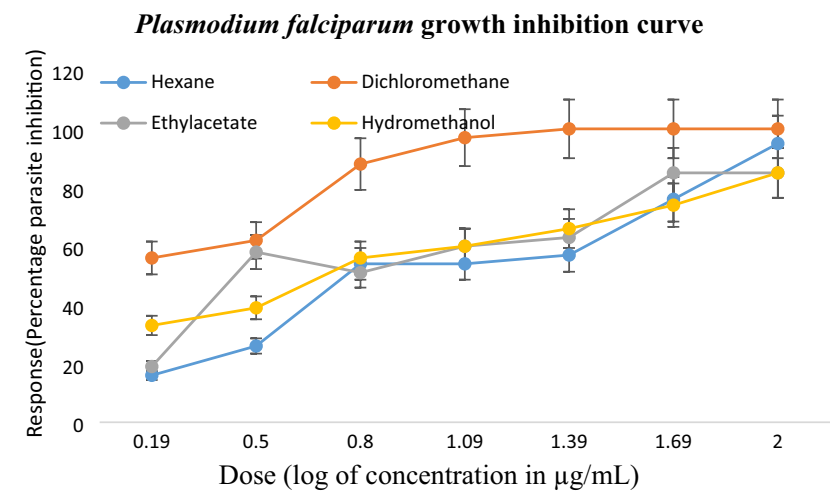

Fig. 3 Dose response curve showing percentage parasite growth inhibition after $48 \mathrm{~h}$ exposure to different doses of $A$. floribunda fractions using Mark III test

\subsection{Gas chromatography with flame ionization detection (GC-FID) analysis on dichloromethane fraction (most active fraction)}

Flavonoids profile of dichloromethane fraction showed the presence of higher level of kaempferol; other flavonoids found in high amount are catechin, naringenin, luteolin, epigallocatechin, quercetin and myricetin (Table 4). Table 5 shows the relatively abundance terpenes, they are azulene, a-pinene, pinene-2-ol, $\gamma$-terpinene, camphor, 1, 8-cineole, borneol, neryl acetate, $\beta$-caryophyllene and humulene. Humulene was significantly higher in the terpenes profile compared to others. Terpenoids profile showed the presence of low $\alpha$-amyrin, and $\beta$-amyrin in the DCM fraction but their concentrations were still much higher than others like taraxerol, lupeol, bauerenol acetate (Table 6). The analyzed $A$. floribunda dichloromethane fraction was generally low in alkaloids and volatile organic constituents (Tables 7 and 8) compared with the flavonoids fingerprint. However, alkaloids such as coniine, coniceine, cassine, spectaline and volatile organic constituents like butanoic acid, 2-methyl butenoic acid were detected in relatively high amount compared to other alkaloids and volatile organic compounds in DCM fraction. See the chromatograms for all the phytochemical fingerprint analyzed in supplementary Fig. S1-S6.

(a) Dose response curve showing percentage parasite growth inhibition after $48 \mathrm{~h}$ exposure to different doses of $A$. floribunda leaf extract, stem bark extract and oil; (b) Dose response curve showing percentage cell viability after $48 \mathrm{~h}$ exposure to different doses of $A$. floribunda leaf and stem bark extracts in Vero cells; (c) Dose response curve showing percentage cell viability after $48 \mathrm{~h}$ exposure to different doses of doxorubicin in Vero cells. Data are expressed as mean \pm SEM of results from three independent experiments. 
Table 4 Names and amount of the various flavonoids present in dichloromethane fraction

\begin{tabular}{|c|c|c|c|c|}
\hline Name & Amount $(\mathrm{mg} / 100 \mathrm{~g})$ & Area & Amount/Area & $\begin{array}{l}\text { Retention } \\
\text { time (min) }\end{array}$ \\
\hline$(+)-$ Catechin & 1.42 & 14.56 & $9.77 \times 10^{-2}$ & 13.75 \\
\hline Resveratrol & $6.61 \times 10^{-8}$ & 0.47 & $1.41 \times 10^{-7}$ & 15.16 \\
\hline Genistein & $9.76 \times 10^{-7}$ & 6.28 & $1.55 \times 10^{-7}$ & 15.50 \\
\hline Daidzein & $5.81 \times 10^{-7}$ & 3.75 & $1.55 \times 10^{-7}$ & 15.63 \\
\hline Apigenin & $2.02 \times 10^{-1}$ & 0.25 & $8.12 \times 10^{-1}$ & 15.75 \\
\hline Daidzein & $3.51 \times 10^{-7}$ & 2.25 & $1.55 \times 10^{-7}$ & 16.31 \\
\hline Butein & $3.21 \times 10^{-7}$ & 2.01 & $1.55 \times 10^{-7}$ & 16.61 \\
\hline Biochanin & $7.2 \times 10^{-7}$ & 4.50 & $1.61 \times 10^{-7}$ & 17.16 \\
\hline Naringenin & 1.40 & 0.10 & 13.74 & 17.29 \\
\hline Luteolin & 1.78 & 0.15 & 12.21 & 17.67 \\
\hline Kaempferol & 12.05 & 52.27 & $2.31 \times 10^{-1}$ & 18.06 \\
\hline$(-)$ - Epicatechin & $8.70 \times 10^{-1}$ & 53.37 & $1.62 \times 10^{-5}$ & 19.52 \\
\hline$(-)$ - Epigallocatechin & 6.27 & 5.37 & $1.17 \times 10^{-5}$ & 20.60 \\
\hline Gallocatechin & $1.34 \times 10^{-5}$ & 27.94 & $4.80 \times 10^{-7}$ & 21.82 \\
\hline Quercetin & 3.38 & 55.59 & $6.07 \times 10^{-2}$ & 22.60 \\
\hline (-) - Epicatechin-3-gallate & $3.06 \times 10^{-5}$ & 7.45 & $4.11 \times 10^{-6}$ & 22.85 \\
\hline$(-)$ - Epigallocatechin-3-gallate & $2.41 \times 10^{-5}$ & 8.48 & $2.84 \times 10^{-6}$ & 23.47 \\
\hline Isorhamnetin & $9.55 \times 10^{-7}$ & 18.95 & $5.04 \times 10^{-8}$ & 23.97 \\
\hline Robinetin & $3.14 \times 10^{-7}$ & 1.99 & $1.57 \times 10^{-7}$ & 24.19 \\
\hline Myricetin & 2.64 & 3.34 & $7.91 \times 10^{-1}$ & 24.79 \\
\hline Baicalein & $2.65 \times 10^{-7}$ & 1.72 & $1.55 \times 10^{-7}$ & 25.17 \\
\hline Nobiletin & $1.21 \times 10^{-7}$ & 7.83 & $1.55 \times 10^{-7}$ & 25.48 \\
\hline Baicalin & $432 \times 10^{-7}$ & 2.78 & $1.56 \times 10^{-7}$ & 25.86 \\
\hline Isoquercetin & $2.09 \times 10^{-3}$ & 3.51 & $5.95 \times 10^{-4}$ & 26.01 \\
\hline Tageretin & $2.02 \times 10^{-7}$ & 1.30 & $1.56 \times 10^{-7}$ & 26.51 \\
\hline Artemetin & $1.71 \times 10^{-7}$ & 1.12 & $1.55 \times 10^{-7}$ & 26.83 \\
\hline Silymarin & $4.67 \times 10^{-8}$ & 0.31 & $1.55 \times 10^{-7}$ & 27.00 \\
\hline Hesperidin & $1.49 \times 10^{-7}$ & 0.21 & $6.93 \times 10^{-7}$ & 28.41 \\
\hline
\end{tabular}

\section{Discussion}

Allanblackia floribunda stem bark extract, leaf extract and oil were examined for their in vitro antiplasmodial activity, the stem bark and leaf infusions were thereafter assessed for their cytotoxic activity; fractionation of the most active extract (stem bark extract) was done with solvents of increasing polarity and phytochemical screening, in vitro antioxidant and antiplasmodial assays were further investigated on the various fractions, finally, phytochemical fingerprint analysis of the most active fraction (dichloromethane) was carried out using gas chromatography with flame ionization detector.

The result of this investigation showed that the inhibition of parasite growth by the plant extracts in vitro was dose dependent, the stem bark and leaf extracts had better antiplasmodial activities compared with the oil which had low activity against the strain of Plasmodium parasite used (Pf3D7). The stem bark extract of $A$. floribunda showed excellent antiplasmodial activity followed by the leaf extract. However, the oil extract had weak activity against $P f 3 D 7$ because the $I C_{50 \text { Pf3D }}$ was over $100 \mu \mathrm{g} / \mathrm{mL}$, hence inactive against the parasite in vitro. $I C_{50}$ is the inhibitory concentrations of the drug/ extracts that can cause $50 \%$ reduction in parasitaemia level. According to the classification of Rasoanaivo et al. [14], the stem extract is considered very active while the leaf extract, is active. This investigation confirms the report of Ayoola et al. [6] and Azebaze et al. [7] that A. floribunda has antiplasmodial activity $[24,25]$. From this investigation, we could establish that the most active part of this plant against chloroquine sensitive $P$. falciparum is the stem bark extract.

The result of the cytotoxicity study showed that the stem and leaf extracts of $A$. floribunda were non-toxic compared with the standard cytotoxic drug, doxorubicin (an anthracycline antibiotic), which was found to be highly cytotoxic. The selectivity indices, a ratio of $\mathrm{CC}_{50}$ to $I C_{50 \text { Pf } 3 D 7}$ revealed that the two extracts were selectively active against the parasite at the concentrations used but 
Table 5 Names and amount of various terpenes present in dichloromethane fraction

\begin{tabular}{|c|c|c|c|c|}
\hline Name & Amount $(\mathrm{mg} / 100 \mathrm{~g})$ & Area & Amount/Area & $\begin{array}{l}\text { Retention } \\
\text { time (min) }\end{array}$ \\
\hline Azulene & 11.15 & 2.34 & 4.76 & 9.46 \\
\hline a-Pinene & 28.35 & 1.44 & 19.69 & 9.83 \\
\hline$\beta$-Pinene & $5.01 \times 10^{-4}$ & 2.63 & $1.90 \times 10^{-4}$ & 10.80 \\
\hline cis-Ocimene & $2.93 \times 10^{-5}$ & 4.48 & $6.53 \times 10^{-6}$ & 12.16 \\
\hline Myrcene & $8.77 \times 10^{-5}$ & 3.64 & $2.41 \times 10^{-5}$ & 12.99 \\
\hline Allo Ocimene & $1.03 \times 10^{-4}$ & 2.88 & $3.59 \times 10^{-5}$ & 13.20 \\
\hline Pinene-2- ol & 1.56 & 0.58 & 2.70 & 13.78 \\
\hline a-Thujene & $1.40 \times 10^{-4}$ & 21.63 & $6.47 \times 10^{-6}$ & 14.16 \\
\hline$\gamma$-Terpinene & 2.08 & 2.37 & $8.80 \times 10^{-1}$ & 14.94 \\
\hline Citral & $1.54 \times 10^{-4}$ & 1.44 & $1.07 \times 10^{-4}$ & 15.11 \\
\hline Camphor & 4.45 & 1.93 & 4.38 & 15.25 \\
\hline Neral & $2.19 \times 10^{-4}$ & 13.45 & $1.62 \times 10^{-5}$ & 15.39 \\
\hline 1,8-Cineole & 3.82 & 8.69 & $4.439 \times 10^{-1}$ & 16.61 \\
\hline Borneol & 6.70 & 5.97 & 1.14 & 17.51 \\
\hline Linalool & $8.25 \times 10^{-5}$ & 6.60 & $1.25 \times 10^{-5}$ & 17.70 \\
\hline Citronellal & $8.25 \times 10^{-5}$ & 4.44 & $1.86 \times 10^{-5}$ & 18.19 \\
\hline Nerol & $8.25 \times 10^{-5}$ & 4.61 & $1.79 \times 10^{-4}$ & 18.45 \\
\hline a-Terpineol & $1.14 \times 10^{-4}$ & 9.38 & $1.22 \times 10^{-5}$ & 18.68 \\
\hline Terpinen-4-ol & $3.97 \times 10^{-1}$ & 12.38 & $3.20 \times 10^{-1}$ & 19.02 \\
\hline Citronellol & $1.51 \times 10^{-4}$ & 13.91 & $1.09 \times 10^{-5}$ & 19.49 \\
\hline a-Terpinenyl acetate & $4.24 \times 10^{-1}$ & 9.84 & $4.31 \times 10^{-2}$ & 21.09 \\
\hline Ethyl cinnamate & $2.45 \times 10^{-4}$ & 7.59 & $3.20 \times 10^{-2}$ & 21.46 \\
\hline Borneol acetate & $3.15 \times 10^{-2}$ & 14.02 & $2.25 \times 10^{-3}$ & 21.61 \\
\hline Neryl acetate & 2.01 & 8.65 & $2.32 \times 10^{-1}$ & 21.71 \\
\hline Geranyl acetate & $7.67 \times 10^{-2}$ & 17.92 & $4.28 \times 10^{-3}$ & 21.85 \\
\hline Germacrene B & $3.61 \times 10^{-4}$ & 18.91 & $1.91 \times 10^{-5}$ & 22.15 \\
\hline$\beta$-Caryophyllene & 3.75 & 11.12 & $3.38 \times 10^{-1}$ & 22.39 \\
\hline Cyperene & $6.04 \times 10^{-5}$ & 11.08 & $5.44 \times 10^{-6}$ & 23.34 \\
\hline [6] - Shogaol & $6.81 \times 10^{-3}$ & 14.82 & $4.60 \times 10^{-6}$ & 24.02 \\
\hline a-Copane & $8.86 \times 10^{-5}$ & 13.25 & $6.69 \times 10^{-6}$ & 24.79 \\
\hline Humulene & 18.82 & 8.01 & 2.35 & 27.76 \\
\hline Valencene & $1.30 \times 10^{-4}$ & 10.52 & $1.23 \times 10^{-5}$ & 28.02 \\
\hline$\beta$-Selinene & $1.04 \times 10^{-4}$ & 16.27 & $6.40 \times 10^{-6}$ & 28.45 \\
\hline Aromadendrene & $1.37 \times 10^{-4}$ & 11.19 & $1.22 \times 10^{-5}$ & 28.75 \\
\hline$\gamma$-Muurolene & $1.32 \times 10^{-4}$ & 1.24 & $1.06 \times 10^{-4}$ & 29.30 \\
\hline
\end{tabular}

Table 6 Names and amount of the various terpenoids present in dichloromethane fraction

\begin{tabular}{lllll}
\hline Name & Amount $(\mathrm{mg} / 100 \mathrm{~g})$ & Area & Amount/Area & $\begin{array}{c}\text { Retention } \\
\text { time (min) }\end{array}$ \\
\hline Taraxerol & $5.89 \times 10^{-4}$ & 189.40 & $3.11 \times 10^{-6}$ & 19.52 \\
a-amyr in & $1.66 \times 10^{-1}$ & 114.17 & $1.45 \times 10^{-3}$ & 20.80 \\
$\beta$-amyrin & $5.56 \times 10^{-1}$ & 156.96 & $3.55 \times 10^{-3}$ & 21.82 \\
Lupeol & $7.82 \times 10^{-2}$ & 95.13 & $8.22 \times 10^{-4}$ & 23.12 \\
Bauerenol acetate & $2.45 \times 10^{-3}$ & 76.36 & $3.27 \times 10^{-5}$ & 24.61 \\
\hline
\end{tabular}


Table 7 Names and amount of the various alkaloids present in dichloromethane fraction

\begin{tabular}{|c|c|c|c|c|}
\hline Name & Amount (mg/100 g) & Area & Amount/Area & $\begin{array}{l}\text { Retention } \\
\text { time (min) }\end{array}$ \\
\hline Dopamine & $5.35 \times 10^{-5}$ & 259.04 & $2.07 \times 10^{-7}$ & 7.92 \\
\hline 3 - methoxytyrarnine & $1.18 \times 10^{-5}$ & 139.20 & $6.12 \times 10^{-8}$ & 9.72 \\
\hline Thiarubrine $\mathrm{A}$ & $2.23 \times 10^{-5}$ & 57.30 & $3.90 \times 10^{-7}$ & 11.06 \\
\hline Aporphine & $2.73 \times 10^{-4}$ & 118.13 & $2.31 \times 10^{-6}$ & 11.35 \\
\hline Crinine & $5.49 \times 10^{-5}$ & 140.61 & $3.91 \times 10^{-7}$ & 13.42 \\
\hline Cherylline & $5.25 \times 10^{-5}$ & 136.34 & $3.81 \times 10^{-7}$ & 13.74 \\
\hline Lycorine & $1.17 \times 10^{-4}$ & 298.53 & $3.90 \times 10^{-7}$ & 14.70 \\
\hline Gelanthamine & $1.92 \times 10^{-4}$ & 502.72 & $3.81 \times 10^{-7}$ & 15.51 \\
\hline Coniine & $1.53 \times 10^{-1}$ & 241.28 & $6.34 \times 10^{-4}$ & 16.04 \\
\hline Crotsparine & $2.42 \times 10^{-3}$ & 342.84 & $7.06 \times 10^{-6}$ & 16.46 \\
\hline Glaziovine & $3.62 \times 10^{-4}$ & 443.74 & $8.15 \times 10^{-7}$ & 16.78 \\
\hline 1,2-dithiin polyyne & $5.05 \times 10^{-5}$ & 311.84 & $1.61 \times 10^{-7}$ & 17.77 \\
\hline Coniceine & $1.52 \times 10^{-1}$ & 428.22 & $3.54 \times 10^{-4}$ & 18.05 \\
\hline Lycopsamine & $1.54 \times 10^{-5}$ & 334.30 & $4.62 \times 10^{-8}$ & 18.59 \\
\hline Echinatine & $3.85 \times 10^{-2}$ & 511.24 & $7.53 \times 10^{-5}$ & 18.93 \\
\hline Montanine & $1.38 \times 10^{-4}$ & 476.94 & $2.89 \times 10^{-7}$ & 19.10 \\
\hline Cassine & $3.77 \times 10^{-1}$ & 1134.34 & $3.32 \times 10^{-4}$ & 19.52 \\
\hline Proaporphine & $4.47 \times 10^{-3}$ & 551.28 & $8.10 \times 10^{-6}$ & 20.47 \\
\hline Hornolycorine & $1.17 \times 10^{-4}$ & 345.21 & $3.38 \times 10^{-7}$ & 21.82 \\
\hline Tazettine & $5.41 \times 10^{-5}$ & 170.80 & $3.16 \times 10^{-7}$ & 22.08 \\
\hline Spectaline & $2.44 \times 10^{-1}$ & 561.44 & $4.35 \times 10^{-4}$ & 22.60 \\
\hline Dicentrine & $2.15 \times 10^{-3}$ & 299.77 & $7.18 \times 10^{-6}$ & 22.85 \\
\hline Albomaculine & $1.23 \times 10^{-4}$ & 171.66 & $7.30 \times 10^{-7}$ & 23.97 \\
\hline 2-Descarboxyl-betanidin & $2.00 \times 10^{-4}$ & 272.22 & $7.53 \times 10^{-7}$ & 24.20 \\
\hline 2-Descarboxyl-betanin & $1.76 \times 10^{-4}$ & 234.07 & $7.53 \times 10^{-7}$ & 24.61 \\
\hline I.soamaranthine & $1.17 \times 10^{-4}$ & 165.37 & $7.10 \times 10^{-7}$ & 25.69 \\
\hline Amaranthin & $3.02 \times 10^{-5}$ & 42.800 & $7.06 \times 10^{-7}$ & 27.29 \\
\hline
\end{tabular}

the stem bark infusion was more selectively toxic to the parasite.

Among the four different fractions obtained from the stem bark extract, hydromethanol, ethylacetate and dichoromethane fractions showed the presence of more bioactive compounds including phenolics, terpenoids, tannins, flavonoids and quinones cardiac glycosides compared with hexane fraction which had the list phytochemicals. In vitro antiplasmodial activity showed that the dichloromethane fraction was highly active against the parasite compared with the ethylacetate, hydromethanol and hexane fractions. Literature report on the antimalaria activity of Allanblackia gabonensis, and Allanblackia monticola had parasite inhibition close to the data obtained for dichloromethane fraction against chloroquine sensitive Plasmodium falciparum [7]. Dichloromethane fraction significantly suppressed the growth of $P$. falciparum compared with ethylacetate, hydromethanol and hexane fractions. The better antimalarial activity of the dichloromethane fraction may be credited to its ability to extract highly active antiplasmodial compounds of flavonoids and terpenes's origin that are intrinsic to A. floribunda stem bark compared with other solvents used for extraction.

GC-FID analysis of $A$. floribunda dichloromethane fractions showed significant levels of flavonoids (kaempferol, catechin, naringenin, luteolin, epigallocatechin, quercetin and myricetin) and terpenes (a-pinene, pinene-2- ol, $\gamma$-terpinene, camphor, 1,8-cineole, borneol, neryl acetate, $\beta$-Caryophyllene, and humulene). However, there appeared to be low levels of terpenoids, alkaloids and volatile organic compounds in the dichloromethane fraction. Some of the phytochemicals present in the dichloromethane fraction have been reported to be potent against $P$. falciparum [26-28]. The better antimalarial activity observed in dichloromethane fraction of $A$. floribunda agrees with the result obtained by Lekana-Douki et al. [29] who used different solvents to extract Tetrapleura tetraptera and Copaifera religiosa. These authors reported that the dichloromethane extract of the aforementioned plants had significant inhibition against parasite growth compared with other solvent used for extraction. 
Table 8 Names and amount of the various volatile organic constituents present in dichloromethane fraction

\begin{tabular}{|c|c|c|c|c|}
\hline Name & Amount (mg/100 g) & Area & Amount/Area & $\begin{array}{l}\text { Retention } \\
\text { time (min) }\end{array}$ \\
\hline Acetic acids & $1.34 \times 10^{-4}$ & 6.75 & $1.96 \times 10^{-5}$ & 6.79 \\
\hline Butanol & $1.05 \times 10^{-3}$ & 6.51 & $1.61 \times 10^{-4}$ & 6.94 \\
\hline Chloromethane & $2.74 \times 10^{-7}$ & 5.60 & $4.90 \times 10^{-8}$ & 7.37 \\
\hline Acrylonitrile & $3.16 \times 10^{-6}$ & 16.05 & $1.97 \times 10^{-7}$ & 7.65 \\
\hline 2-Propenal & $3.63 \times 10^{-7}$ & 2.64 & $1.38 \times 10^{-7}$ & 8.50 \\
\hline Chloroethane & $1.51 \times 10^{-8}$ & 1.26 & $1.20 \times 10^{-7}$ & 9.14 \\
\hline Bromomethane & $1.82 \times 10^{-8}$ & 2.48 & $7.52 \times 10^{-8}$ & 9.33 \\
\hline Benzene & $7.36 \times 10^{-8}$ & 4.56 & $1.61 \times 10^{-7}$ & 9.46 \\
\hline Butanoic acid & $8.49 \times 10^{-2}$ & 41.43 & $2.05 \times 10^{-2}$ & 9.69 \\
\hline Toluene & $6.73 \times 10^{-8}$ & 9.75 & $6.91 \times 10^{-8}$ & 10.00 \\
\hline Ethylbenzene & $1.18 \times 10^{-7}$ & 1.45 & $8.13 \times 10^{-8}$ & 10.28 \\
\hline p-xylene & $1.45 \times 10^{-7}$ & 1.79 & $8.11 \times 10^{-8}$ & 10.40 \\
\hline m-xylene & $2.31 \times 10^{-7}$ & 1.17 & $1.97 \times 10^{-7}$ & 10.80 \\
\hline o-xylene & $9.25 \times 10^{-8}$ & 3.36 & $2.75 \times 10^{-8}$ & 11.17 \\
\hline 2-Methyl Butenoic acid & 1.09 & 94.28 & $1.15 \times 10^{-2}$ & 11.37 \\
\hline Chloroethyl vinyl ether & $3.85 \times 10^{-7}$ & 2.48 & $1.55 \times 10^{-7}$ & 11.58 \\
\hline cis-1,3-Dichloropropene & $2.09 \times 10^{-6}$ & 5.30 & $3.95 \times 10^{-7}$ & 12.01 \\
\hline trans-1,3-Dichloropropene & $2.54 \times 10^{-7}$ & 1.58 & $1.61 \times 10^{-7}$ & 12.44 \\
\hline 1,1-Dichloropropene & $1.34 \times 10^{7}$ & 27.85 & $4.80 \times 10^{-7}$ & 12.83 \\
\hline 2,2-Dichloropropane & $7.39 \times 10^{-8}$ & 9.11 & $8.12 \times 10^{-8}$ & 13.08 \\
\hline 1,3-Dichloropropane & $5.64 \times 10^{-8}$ & 9.33 & $6.04 \times 10^{-8}$ & 13.21 \\
\hline Dichlorodifluoromethane & $1.14 \times 10^{-7}$ & 1.89 & $6.05 \times 10^{-8}$ & 13.62 \\
\hline 2-Methyl Butanoic acid & $1.53 \times 10^{-7}$ & 1.31 & 1.17 & 13.78 \\
\hline o-Chlorotoluene & $1.65 \times 10^{5}$ & 27.31 & $6.06 \times 10^{-7}$ & 14.16 \\
\hline 2-Methyl Butenoic acid ethyl ester & $9.61 \times 10^{-7}$ & 1.00 & $9.60 \times 10^{-1}$ & 14.51 \\
\hline Bromochloromethane & $3.72 \times 10^{-7}$ & 4.59 & $8.12 \times 10^{-8}$ & 14.77 \\
\hline (1-Methylpropyl) benzene & $1.78 \times 10^{-7}$ & 2.19 & $8.11 \times 10^{-8}$ & 15.04 \\
\hline (1,1-Diethylethyl) benzene & $3.12 \times 10^{-7}$ & 2.83 & $1.10 \times 10^{-7}$ & 15.50 \\
\hline 1,4-Dichloro benzene & $5.25 \times 10^{-8}$ & 1.28 & $4.11 \times 10^{-8}$ & 15.80 \\
\hline 1,3-Dichloro benzene & $5.44 \times 10^{-7}$ & 6.62 & $8.22 \times 10^{-8}$ & 16.13 \\
\hline 1,2,3-Trichloropropane & $4.75 \times 10^{-6}$ & 15.97 & $2.98 \times 10^{-7}$ & 16.55 \\
\hline 1,2-Dichloroben zene & $6.16 \times 10^{-7}$ & 3.90 & $1.58 \times 10^{-7}$ & 17.09 \\
\hline Bromobenzene & $1.60 \times 10^{-7}$ & 1.04 & $1.55 \times 10^{-7}$ & 17.33 \\
\hline 2-Methyl Butanoic acid ethyl ester & $1.05 \times 10^{-1}$ & 13.41 & $7.81 \times 10^{-3}$ & 17.64 \\
\hline 1,1,1,2-Tetrachloroethane & $6.85 \times 10^{8}$ & 1.13 & $6.06 \times 10^{-8}$ & 18.01 \\
\hline 1,2,3-Trichlorobenzene & $3.20 \times 10^{-7}$ & 2.07 & $1.55 \times 10^{-7}$ & 19.01 \\
\hline Hexachloro-1,3-butadiene & $6.38 \times 10^{-8}$ & 0.41 & $1.55 \times 10^{-7}$ & 20.74 \\
\hline
\end{tabular}

Literature has earlier reported that some of these compounds detected in dichloromethane fraction have strong inhibitory activity against chloroquine sensitive and chloroquine resistant strains of $P$. falciparum [30, 31]. Although the mechanism by which $A$. floribunda inhibited PF3D7 growth has not been identified, however some malaria researchers have suggested possible ways by which the pharmacologically active compounds (flavonoids and terpenes) which were detected in A. floribunda can exhibit schizonticidal activity against Plasmodium parasite. Herbert et al. [32] reported that terpenes are capable of inhibiting Plasmodium parasite growth because of the structural similarity it has to the substrate needed for isoprenoids biosynthesis in Plasmodium parasite. Isoprenoids' biosynthesis depends on the DOXP/2C-methyl-d-erythritol-4-phosphate (MEP) pathway in Plasmodium falciparum [33] while in humans, isoprenoids are synthesized via the mevalonate pathway [34]. This made isoprenoid biosynthesis a potential target for $P$. falciparum especially in the presence of phytochemicals such as terpenes. Terpenes inhibit dolichol biosynthesis in the trophozoite and schizont stages and it may 
be acting through inhibition of the isoprenyl diphosphate synthases [32]. This family of enzymes catalyzes consecutive 1'-4 condensations of isopentenyl-pyrophosphate with the allylic substrate to form the linear backbone for all isoprenoid compounds, including prenylated proteins, prenylated quinones, and dolichol [35]. Due to the structural similarity terpenes have with the substrates required for dolichol synthesis, it might interfere with the parasite's biosynthesis of polyisoprenoids by competing with original substrates in enzyme-substrate reactions or by interfering with the mechanisms of elongation of isoprenic chains [32]. This metabolic interference may have accelerated parasite death when chloroquine-sensitive $P$. falciparum culture at ring stage were treated with $A$. floribunda stem bark infusion. Other possible mechanisms of parasite inhibition by the plant extracts could be through parasite enzyme inhibition (1, 5-lipoxygenase, carbonic anhydrase, and aspartic protease) by phenolics [31], prevention of merozoites invasion of erythrocytes by flavonoids, inhibition of haemozoin biocrystallization by alkaloids, inhibition of $P$. falciparum fatty acid biosynthesis and protein synthesis disruption by triterpenoids [36-39].

\section{Conclusions}

Findings from this study show that $A$. floribunda methanol stem bark and leaf extracts have some levels of activity against Plasmodium falciparum parasite and are relatively non-toxic to normal cells. Dichloromethane fraction was the most active fraction from the stem bark extract. Based on the GC-FID results, we are suggesting that flavonoids and terpenes may have been responsible for the excellent antimalarial activity of $A$. floribunda stem bark extract. This therefore supports the use of $A$. floribunda in the treatment of malaria in ethno-medicinal practices. The next phase of this study is to conduct activity guided isolation on the dichloromethane fraction to obtain the active antimalarial compound in A. floribunda stem bark.

Acknowledgements The authors would like to acknowledge the Department of Biochemistry, university of Benin; Department of Basic Sciences, Benson Idahosa University; Department of Cell Biology, University of Lagos; Department of Biochemistry, National Institute of Medical Research and Metro Research and Biotechnology Africa Limited for their technical supports and research facilities.

Authors' contributions All authors contributed to the study conception and design. Material preparation, data collection and analysis were performed by $\mathrm{FI}, \mathrm{OE}, \mathrm{NE}$ and OT. O. The first draft of the manuscript was written by $\mathrm{Fl}$ and all authors commented on previous versions of the manuscript. All authors read and approved the final manuscript.
Funding This work received financial support from Obariase Foundation. Equally, the in vitro testing was materially supported by Dr. O.A. Adebesin, Department of Cell Biology and Genetics, University of Lagos.

\section{Declarations}

Conflict of interests The authors declare that they have no competing interests.

Ethics approval The study was approved by the Institutional Ethics Review Committee, University of Benin (LS19114).

Data Availability All data generated and analyzed are included in this research article.

Open Access This article is licensed under a Creative Commons Attribution 4.0 International License, which permits use, sharing, adaptation, distribution and reproduction in any medium or format, as long as you give appropriate credit to the original author(s) and the source, provide a link to the Creative Commons licence, and indicate if changes were made. The images or other third party material in this article are included in the article's Creative Commons licence, unless indicated otherwise in a credit line to the material. If material is not included in the article's Creative Commons licence and your intended use is not permitted by statutory regulation or exceeds the permitted use, you will need to obtain permission directly from the copyright holder. To view a copy of this licence, visit http://creativecommons. org/licenses/by/4.0/.

\section{References}

1. Trampuz A, Jereb M, Muzlovic I, Prabu RM (2003) Clinical review: severe malaria. Crit Care 7(4):315-323. https://doi.org/10.1186/ cc2183

2. World Health Orgnization (2018) World malaria report. Geneva: https://apps.who.int/iris/bitstream/handle/10665/275867/ 97892 41565653-eng.pdf?ua $=1$

3. Ajayi NA, Ukwaya KN (2013) Possible ACT resistant malaria in Nigeria - a report of 3 cases. Rev Soc Bras Med Trop 46(4):525-527

4. Wundermann GS, Osiki AA (2017) Currently observed trend in the resistance of malaria to artemisinin based combination therapy in Nigeria - a report of 5 cases. Int $j$ trop dis health 21(2):1-5

5. .Ebohon O, Irabor F, Ebohon LO, Omoregie ES, (2019) Therapeutic failure after regimen with artemether-lumefantrine combination therapy: a report of three cases in Benin City Nigeria. Rev Soc Bras Med Trop 52:e20190163

6. Ayoola GA, Coker HA, Adesegun SA, Adepoju-Bello AA, Obaweya K, Ezennia EC (2008) Phytochemical screening and antioxidant activities of some selected medicinal plants used for malaria therapy in Southwestern Nigeria. Trop J Pharm Res 7:1019-1024

7. Azebaze AGB, Teinkela JEM, Nguemfo EL, Valentin A, Dongmo $A B$, Vardamides JC (2015) Antiplasmodial activity of some phenolic compounds from Cameroonians Allanblackia. Afri Health Sci 15(3):835-840

8. .Boudjeko T, Ngomoyogoli KEJ, Woguia LA, Yanou NN, (2013) Partial characterization, antioxidative properties and hypolipidemic effects of oilseed cake of Allanblackia floribunda and Jatropha curcas. BMC Complem Altern M 13:352. https://doi. org/10.1186/1472-6882-13-352

9. Adu JK, Amoah E, Ayensu I, Osei-Djarbeng S, Peter J (2016) Phytochemical screening and antimicrobial.activities of the stem 
bark of Allanblackia parviflora Chev (Clusiaceae). J of phytopharmacol 5 (6) 215-219

10. Akpanika GA, Winters A, Wilson T, Ayoola GA, AA, Bello A, Hauck $B$, (2017) Polyphenols from Allanblackia floribunda seeds: identification, quantification and antioxidant activity. Food Chem 222:35-42. https://doi.org/10.1016/j.foodchem.2016.12.002

11. Trager W, Jensen JB (1976) Human malaria in continuous culture. Science 193:673-675

12. Olasehinde GI, Olusola $O$, Adegboyeg OA, Obasola EF, Neena V, Isaac OA, Adesola AA, Louis OE (2014) In vitro studies on the sensitivity pattern of Plasmodium falciparum to anti-malarial drugs and local herbal extracts. Mala J 13:63

13. WHO (2001) In vitro micro-test (Mark III) for the assessment of $P$. falciparum to, mefloquine, quinine, amodiaquine, sulfadoxine/pyrimethamineand artemisinin. Geneva, Switzerland: CTD/ MAL/9720 Rev 2

14. Rasoanaivo A, Ravi P, Petitjean S, Ratsimamanga-Urverg A, Rakoto R (1992) Medicinal plants used to treat malaria in Madagascar. J Ethnopharmacol 37:117-127

15. Mosmann T (1983) Rapid colorimeter assay for cellular growth and survival: application to proliferation and cytotoxicity assays. $\mathrm{J}$ Immunol Methods 65(1-2):55-63

16. Hassan ES, Verma S, Srivastava SK, Dwarn S (2013) Activity guided isolation and characterization of antiplasmodial agents of some local medicinal plants. Nig J Basic Appl Sci. https://doi. org/10.4314/njbas.v21i3.2

17. Trease GE, Evans WC (1989) Pharmacognosy. $11^{\text {th }}$ edition London Bailliere Tindall Ltd Pp. $60-75$.

18. Harborne JB (1973) Phytochemical Methods, London, Chapman and Hall, Ltd. Pp. 49-188

19. Brand-Williams W, Cuvelier ME, Berset C (1979) Use of a free radical method to evaluate antioxidant activity. LWT-Food Sci Technol 28:25-30

20. Prieto P, Pineda M, Anguilar M (1999) Spectrophotometric quantitation of antioxidant capacity through the formation of a phosphomolybdenum complex: specific application to the determination of Vit E. Analytical Biochem 269:337-341

21. Millogo-Kone H, Lompo M, Kini F, Asimi S, Guissou IP, Nacoulma $O$ (2009) Evaluation of flavonoids and total phenolic contents of stem bark and leaves of Parkia biglobosa (Jacq.) Benth. (Mimosaceae) - free radical scavenging and antimicrobial activities. Res J Med Sci 3(2):70-74

22. Ortan A, Popescu M, Gaita A, Dinu-Pirvu C, Campeanu G (2009) Contribution to the pharmacological study on Anethum graveolens, Dill (Apiaceae). Romanian Biotechnol Lett 14(2):4342-4348

23. Ngounou FN, Manfouo RN, Tapondjou LA, Lontsi D, Kuete V (2005) Antmicrobial diterpenoids alkaloids from Erythrophleum Suaveoleus. Bull Chem Soc Ethiop 19(2):221-226

24. Burkill HM (1985) The useful plants of West Tropical Africa. Royal Botanical Garden Kew 4:385-386

25. Odugbemi TO (2006) Outlines and Pictures of Medicinal Plants from Nigeria. University of Lagos Press, Lagos, Nigeria, p 137

26. Salehi $B$, Upadhyay $S$, Orhan IE, Jugran AK, Jayaweera SLD, Dias DA, Sharopov F, Taheri Y, Martins N, Baghalpour N, Cho WC,
Sharifi-Rad J (2019) Therapeutic Potential of $\alpha$ - and $\beta$-Pinene. A Miracle Gift of Nature Biomol 9(11):738. https://doi.org/10.3390/ biom9110738

27. Soré H, Sanon S, Hilou A (2018) Antiplasmodial properties of plants isolated flavonoids and their derivatives. Int. J Herb Med 6(5). 43-56. wwwflorajournal.com

28. Kamaraj C, Balasubramani G, Siva C, Raja M, BalasubramanianV., Raja RK, Tamilselvan S, Benelli G, Perumal P, (2017) Ag nanoparticles synthesized using b-caryophyllene isolated from murraya koenigii: antimalarial (plasmodium falciparum 3D7) and anticancer activity (A549 and HeLa cell lines). J Clust Sci 28:1667-1684

29. Lekana-Douki JB, Oyegue Liabagui SL, Zatra BJB, R, Lebibi J, Toure-Ndouo, FS, (2011) In vitro antiplasmodial activity of crude extracts of Tetrapleura tetraptera and Copaifera religiosa. BMC Res Notes 4:506. https://doi.org/10.1186/1756-0500-4-506

30. Zofou D, Kowa TK, Wabo HK, Ngemenya MN, Tane P, Titanji VPK (2011) Hypericum lanceolatum (Hypericaceae) as a potential source of new anti-malarial agents: a bioassay-guided fractionation of the stem bark. Malar J 10:167

31. Pham AT, Nguyen C, Malterud KE, Diallo D, Wangensteen H (2013) Bioactive favone-C-glycosides of the African medicinal plant Biophytumum braculum. Molecules 18:10312-10319

32. Herbert RG, Emília AK, Valnice JP, Alicia SC, Fulgencio AAD, Alejandro MK (2004) Terpenes Arrest Parasite Development and Inhibit Biosynthesis of Isoprenoids in Plasmodium falciparum. Antimicrob Agents Chemother 48(7):2502-2509

33. Jomaa $H$, Wiesner J, Sanderbrand $S$, Altincicek B, Weidemeyer C, Hintz M, Turbachova I, Eberl M, Zeidler J, Lichtenthaler HK, Soldati D, Beck E (1999) Inhibitors of the nonmevalonate pathway of isoprenoid biosynthesis as antimalarial drugs. Science 285:1573-1576

34. Goldstein JL, Brown MS (1990) Regulation of the mevalonate pathway. Nature 343:425-430

35. Wang KC, Ohnuma S (2000) Isoprenyl diphosphate synthases. Biochem Biophys Acta 1529:33-48

36. Ravikumar S, Inbaneson SJ, Suganthi P (2012) In vitro antiplasmodial activity of ethanolic extracts of South Indian medicinal plants against Plasmodium falciparum. Asian Pac J Trop Biomed 1-9 Available at: www.elsevier.com/locate/apjtb

37. Kirby GC, O'Neil MJ, Philipson JD, Warhurst DC (1989) In vivo studies on the mode of action of quassinoids with activity against chloroquine resistant Plasmodium falciparum. Biochem Pharmacol 38:4367-4374

38. Dubar F, Egan TJ, Pradines B, Kuter D, Ncokazi KK, Forge D (2011) The antimalarial ferroquine: role of the metal and intramolecular hydrogen bond in activity and resistance. ACS Chem Biol 6(3):275-287

39. Wright CW (2009) Antiprotozoal Natural Products. In: Evans EC (ed) Trease and Evans Pharmacognosy, 16th edn. Edinburgh, Saunders, pp 428-434

Publisher's Note Springer Nature remains neutral with regard to jurisdictional claims in published maps and institutional affiliations. 